\title{
Inhaltsfahne
}

https://doi.org/10.1515/bfp-2018-0048

Diese Inhaltsfahne darf gebührenfrei vervielfältigt werden (DIN 1428).

Stefan Münnich: Ontologien als semantische Zündstufe für die digitale Musikwissenschaft? Eine Bestandsaufnahme In: BIBLIOTHEK 42 (2018) Nr. 2, S. 184-193

Zusammenfassung: Ontologien spielen eine zentrale Rolle für die formalisierte Repräsentation von Wissen und Informationen sowie für die Infrastruktur des sogenannten semantic web. Trotz früherer Initiativen der Bibliotheken und Gedächtnisinstitutionen hat sich die deutschsprachige $\mathrm{Mu}$ sikwissenschaft insgesamt nur sehr zögerlich dem Thema genähert. Im Rahmen einer Bestandsaufnahme werden neben der Erläuterung grundlegender Konzepte, Herausforderungen und Herangehensweisen bei der Modellierung von Ontologien daher auch vielversprechende Modelle und bereits erprobte Anwendungsbeispiele für eine ,semantische' digitale Musikwissenschaft identifiziert.

Schlüsselwörter: Semantic Web; Ontologien; Wissensrepräsentationen; Digitale Musikwissenschaft

Pasquale Lisena, Manel Achichi, Pierre Choffé, Cécile Cecconi, Konstantin Todorov, Bernard Jacquemin und Raphaël Troncy: Improving (Re-) Usability of Musical Datasets: An Overview of the DOREMUS Project [Verbesserung der (Wieder)Verwendbarkeit von Musikdaten: Ein Überblick über das DOREMUS-Projekt] In: BIBLIOTHEK 42 (2018) Nr. 2, S. 194-205

Zusammenfassung: Das DOREMUS-Projekt strebt eine bessere Beschreibung von Musik an, indem es Daten dreier französischer Institutionen untersucht und zusammenführt. Der vorliegende Artikel gibt einen Überblick über das auf FRBRoo basierende Datenmodell, das die automatische Umwandlung und Verlinkung von Daten ermöglicht. Er stellt Prototypen vor, wie die Daten nach den Bedürfnissen der Webnutzer verarbeitet werden können.

Schlüsselwörter: FRBRoo; Musikwerke; semantisches Web; Datenumwandlung; Data Linking; Musikpraktiken; Empfehlungssystem

Terhi Nurmikko-Fuller, Daniel Bangert, Alan Dix, David Weigl und Kevin Page: Building Prototypes Aggregating Musicological Datasets on the Semantic Web [Die Erstellung prototypischer Anwendungen von verknüpften musikwissenschaftlichen Datensätzen]
In: BIBLIOTHEK 42 (2018) Nr. 2, S. 206-221

Zusammenfassung: Semantische Web-Technologien wie RDF, OWL und SPARQL ermöglichen die Verknüpfung von komplementären musikwissenschaftlichen Daten. In diesem Artikel beschreiben, vergleichen und bewerten wir die Datensätze und Workflows, die zur Erstellung zweier solcher Aggregationsprojekte verwendet wurden: In Collaboration with In Concert und JazzCats, die jeweils Sammlungen kleinerer Projekte mit Konzert- und PerformanceMetadaten zusammenführen.

Schlüsselwörter: Musikwissenschaft; Ontologie; Workflow

Katrin Bicher und Barbara Wiermann: Normdaten zu „Werken der Musik“ und ihr Potenzial für die digitale Musikwissenschaft

In: BIBLIOTHEK 42 (2018) Nr. 2, S. 222-235

Zusammenfassung: Der Aufsatz diskutiert Normdaten zu musikalischen Werken in der GND und erörtert Möglichkeiten ihrer (Nach-)Nutzung in bibliothekarischen und musikwissenschaftlichen Kontexten. Herausforderungen sowohl des theoretischen Konzepts als der praktischen Umsetzung werden benannt und das Potenzial der in den Normdaten enthaltenen Informationen wird aufgezeigt.

Schlüsselwörter: Normdaten; musikalische Werke; Bibliothekskatalog; digitale Musikwissenschaft

Andreas Münzmay: Lesen und Schreiben im digitalen Dickicht. Musikwissenschaft, Digital Humanities und die hybride Musikbibliothek

In: BIBLIOTHEK 42 (2018) Nr. 2, S. 236-246

Zusammenfassung: Digitalisierung generiert ,hybride‘ $\mathrm{Ob}$ jekte, die zwar als digitale Datei lesbar und manipulierbar sind, das zugrundeliegende kulturhistorische Objekt jedoch weiterhin ,enthalten'. Eine Bibliothek, die Objekte aus ihren Beständen digitalisiert, begründet also eigentlich keine sog. digitale Bibliothek, sondern eine hybride Bibliothek. Im Falle musikalischer Überlieferung ist die Sachlage aufgrund der medienhistorischen Komplexität musikalischer Artefakte besonders unübersichtlich. Verschärft wird die heutige Situation noch durch die Erzeugnisse der Digital Humanities, die keineswegs bloß ,Informationen' sind, sondern ihrerseits komplexe und in der Regel hybride Textgebilde, die häufig komplette digitalisierte Re-Publikationen von Kulturobjekten einbinden, die digital ,beschriftet‘ und vernetzt werden. Das digitale ,Dickicht' erfordert einen gleichsam genetischen und relatio- 
nalen Katalog, in dem die konkreten kulturhistorischen Objekte in ihren konkreten Sammlungskontexten - also als Unikate-Ankerfunktion haben.

Schlüsselwörter: Hybride Objekte; Digitale Bibliothek; Digital Humanities; Metadaten; Katalog

Christiane Hausmann: Bach digital: Ein „work in progress“ der digitalen Musikwissenschaft In: BIBLIOTHEK 42 (2018) Nr. 2, S. 247-254

Zusammenfassung: Der Beitrag zeichnet die inhaltlichtechnische Entwicklung der Komponistendatenbank Bach digital nach und erläutert ihre Zielsetzungen. Damit einhergehend werden einerseits die Herausforderungen und Probleme digitaler Langezeitprojekte benannt. Andererseits wird dargestellt, wie durch die Entwicklung eines komplexen digitalen Recherche-Instruments die Organisation und Präsentation von Forschungsergebnissen transformiert werden und welche Veränderungen sich dadurch für das musikwissenschaftliche Arbeiten und die Forschungskommunikation ergeben.

Schlüsselwörter: Digitalisierung; Komponistendatenbank; J.S. Bach; Bach-Familie

Patrizia Rebulla, Pierluigi Ledda und Helen Müller: The letters of Casa Ricordi [Bertelsmann und das Archivio Storico Ricordi] In: BIBLIOTHEK 42 (2018) Nr. 2, S. 255-262

Zusammenfassung: Das Archivio Storico Ricordi sammelt historische Materialien eines der bedeutendsten Musikverlagshäuser aller Zeiten. Über fast 200 Jahre prägten die Ricordis nicht nur durch ihre Verlagstätigkeit, sondern ebenso als Impresarios, Agenten, Kulturförderer und -manager das italienische Musikleben. Rund 30000 an die Ricordis gerichtete autografe Schreiben von Komponisten, Schriftstellern, Librettisten, Sängern und Dirigenten sowie 600000 von den Ricordis verfasste Briefe dokumentieren die herausragende Rolle der Verlegerfamilie. Die gesamte Sammlung wird nach und nach online zur Verfügung gestellt. Dabei werden die Schriftstücke nicht nur mit anderen Objekten des Ricordi-Archivs wie Verlagsbüchern, Verträgen, Bühnenentwürfen, Noten, Bildern, sondern ebenso mit Materialien anderer Musikerarchive im Web verlinkt.

Schlüsselwörter: Verlagsarchiv; Brieferschließung; Handschriften-OCR; Crowdsourcing
Frédéric Lemmers: Digitizing Sound Archives at Royal Library of Belgium. Challenges and difficulties encountered during a major digitization project

[Please insert translated article title]

In: BIBLIOTHEK 42 (2018) Nr. 2, S. 263-271

Zusammenfassung: Musikalien im Allgemeinen und Tonträger im Besonderen erhalten in bibliothekarischen Digitalisierungsstrategien häufig nur wenig Beachtung, obwohl gerade für Wachszylinder und Schellackplatten sowohl aus Gründen der Bestandserhaltung als auch zur Verbesserung der Zugänglichkeit ihre Digitalisierung dringend geboten wäre. Um bei der Retrodigitalisierung von historischen Tonaufnahmen künstlerisch und wissenschaftlich zuverlässige Ergebnisse zu erreichen, ist den originalen Aufnahmetechniken große Aufmerksamkeit zu schenken. Die Königliche Bibliothek Belgiens lässt seit 2016 ihre vollständige Sammlung an Schellackplatten digitalisieren. Mithilfe eines Dienstleisters werden ca. 4000 Stunden Tonaufnahmen produziert, die für aufkommende Forschungsfragen der digitalen Musikwissenschaft einen gewichtigen Quellenkorpus darstellen.

Schlüsselwörter: Tonaufnahmen; Digitalisierung; Nutzererwartungen; Audio-Turn

Karolin Schmahl: Open Cultural Heritage - zum Hören! In: BIBLIOTHEK 42 (2018) Nr. 2, S. 272-283

Zusammenfassung: Digitale oder digitalisierte Tonaufnahmen sind zunehmend gefragte, wichtige Quellen für die Wissenschaft und als Dokumente des kulturellen Erbes auch für eine breite Öffentlichkeit von großem Interesse. Die Online-Bereitstellung frei zugänglicher Audiodokumente als Open Cultural Heritage erweist sich für Bibliotheken und Archive in der Praxis jedoch häufig als schwierig. Der Beitrag umreißt die besonderen Herausforderungen bei der Digitalisierung und Bereitstellung von Tondokumenten und skizziert - auch anhand von Praxisbeispielen - verschiedene Wege, auf denen Sammlungen den Anforderungen von Open Science gerecht werden können.

Schlüsselwörter: Audiomaterialien; Open Science; Digitalisierung

Christian Liebl: Zur Edition historischer Tonaufnahmen ein Praxisbericht In: BIBLIOTHEK 42 (2018) Nr. 2, S. 284-291

Zusammenfassung: Auf Basis der Praxis des Phonogrammarchivs der Österreichischen Akademie der Wissenschaften präsentiert der Beitrag neben einigen generellen Überlegungen zwei Workflows zu inhaltlichen und technischen Aspekten einer kommentierten Edition historischer Tonaufnahmen. Thematisiert werden u.a. die quel- 
lenkritische Aufbereitung und Kontextualisierung sowie Re-recording, Digitalisierung und Signalverbesserung.

Schlüsselwörter: Historische Tonaufnahmen; Edition; Rerecording; Signalverbesserung

Joachim Veit und Kristina Richts: Stand und Perspektiven der Nutzung von MEl in der Musikwissenschaft und in Bibliotheken In: BIBLIOTHEK 42 (2018) Nr. 2, S. 292-301

Zusammenfassung: Ausgehend von einer Darstellung der (an TEI angelehnten) Entwicklung von MEI werden die Forschungsperspektiven des Einsatzes dieses für wissenschaftliche Zwecke geschaffenen Formats und speziell das Potential seines umfangreichen Header-Bereichs beschrieben. Am Beispiel der Rolle von Faksimiles in Editionen wird deutlich, wie dieses Format zu einer neuen Zusammenarbeit von Wissenschaft und Bibliotheken beitragen kann.

Schlüsselwörter: Datenstandards; Music Encoding Initiative (MEI); Metadaten; TEI

Daniel Röwenstrunk: Langzeitverfügbarkeit von wissenschaftlicher Software im Bereich historisch-kritischer Musikedition In: BIBLIOTHEK 42 (2018) Nr. 2, S. 302-308

Zusammenfassung: Die Langzeitverfügbarkeit von Forschungsergebnissen und der dafür häufig notwendige langfristige Erhalt der Lauffähigkeit von Software ist eine gemeinschaftliche Herausforderung für Forschung, Softwareentwicklung und Gedächtnisinstitutionen. Es stehen verschiedene Maßnahmen wie Standardisierung, Emulation oder auch die Weiterentwicklung durch Open-SourceCommunities zur Verfügung, die in unterschiedlichen Kontexten für unterschiedliche Arten von Software zum Einsatz kommen können.

Schlüsselwörter: Forschungssoftware; Langzeitverfügbarkeit; Digitale Musikedition

Klaus Keil und Laurent Pugin: Das Internationale Quellenlexikon der Musik, RISM. Ein Gemeinschaftsprojekt zum Nutzen und als Aufgabe für Forschung und Bibliotheken In: BIBLIOTHEK 42 (2018) Nr. 2, S. 309-318

Zusammenfassung: Das Internationale Quellenlexikon der Musik (RISM) ist ein internationales Gemeinschaftsprojekt mit dem Ziel, die weltweit überlieferten Quellen zur Musik umfassend zu dokumentieren. Es bietet einen Online-Katalog, der Bibliothekaren, Musikern, Wissenschaftlern und allen interessierten Personen kostenlos zur Verfügung steht. Zunehmend gerät aber der Austausch von Daten in den Vordergrund, sei es von lokalen OnlineBibliothekskatalogen zu RISM oder umgekehrt. Für die
Wissenschaft dürfte die Nachnutzung der Daten, die sowohl als Open Data als auch Linked Open Data bereitstehen, in Spezialprojekten von Interesse sein.

Schlüsselwörter: Musikquellen; Online-Erschließung; Normdaten; MEI; Visualisierung; Digitalisate; IIIF

Jürgen Diet: Optical Music Recognition in der Bayerischen Staatsbibliothek

In: BIBLIOTHEK 42 (2018) Nr. 2, S. 319-323

Zusammenfassung: Die Bayerische Staatsbibliothek hat im Sommer 2016 ein Projekt zur automatischen Notenerkennung (Optical Music Recognition, OMR) gestartet. Dieser Beitrag beschreibt zunächst die Funktionsweise und die Qualität von OMR-Programmen und geht dann auf die bisherigen Erfahrungen der Bayerischen Staatsbibliothek mit OMR ein. Anschließend werden die Anwendungsszenarien skizziert, die die Bayerische Staatsbibliothek aufsetzend auf den OMR-Daten entwickeln wird.

Schlüsselwörter: Optical Music Recognition; Notenerkennung; Melodie-Suche

Manuel Burghardt: Digital Humanities in der Musikwissenschaft - Computergestützte Erschließungsstrategien und Analyseansätze für handschriftliche Liedblätter In: BIBLIOTHEK 42 (2018) Nr. 2, S. 324-332

Zusammenfassung: Der Beitrag beschreibt ein laufendes Projekt zur computergestützten Erschließung und Analyse einer großen Sammlung handschriftlicher Liedblätter mit Volksliedern aus dem deutschsprachigen Raum. Am Beispiel dieses praktischen Projekts werden Chancen und Herausforderungen diskutiert, die der Einsatz von Digital Humanities-Methoden für den Bereich der Musikwissenschaft mit sich bringt.

Schlüsselwörter: Digital Humanities; Crowdsourcing; Optical Music Recognition; Music Information Retrieval; Melodic Similarity

Hans-Christoph Hobohm: Warum brauchen wir eine (neue) Bibliothekswissenschaft? Editorial In: BIBLIOTHEK 42 (2018) Nr. 2, S. 333-337

Zusammenfassung: Die Medienschwelle, an der wir uns befinden, stellt viele Institutionen infrage. Nicht aber die Bibliothek, wie viele äußerst erfolgreiche neue Bibliotheksprojekte (ÖB und WB) belegen. Der Themenschwerpunkt lässt (auch anlässlich der Next Library Conference in Berlin im September 2018) unterschiedliche Wissenschaftler zu Wort kommen, die dafür plädieren, sich auch wissenschaftlich mit dem Phänomen Bibliothek (wieder) zu befassen, um besser zu verstehen, wie ihre Potentiale den digitalen Wandel positiv begleiten können. 
Schlüsselwörter: Bibliothekswissenschaft; Erneuerung; Dataismus; Wissen; soziale Erkenntnistheorie

\section{R. David Lankes: Why Do We Need a New Library Science} [Warum wir eine neue Bibliothekswissenschaft brauchen] In: BIBLIOTHEK 42 (2018) Nr. 2, S. 338-343

Zusammenfassung: Die Bibliothek als Wissensmaschine und das Lesen als ihr Motor ist eine überkommene Vorstellung des Industriezeitalters. Auch das Informationsparadigma, das Information als Ding und IT-Strukturen als neutral betrachtete, entspricht nicht mehr den Erfordernissen unserer Zielgruppen im digitalen Datenzeitalter. Nicht Informationsressourcen, Medien, Technik und Gebäude sind der „Bestand“ einer Bibliothek, sondern die kreativen, Wissen schaffenden Mitglieder ihrer Communities mit all ihren Geschichten und sehr diversen Ansichten. Es ist Zeit, nicht mehr auf Daten und Information, sondern auf die Fragen der Produktion und des Verständnisses von Wissen als Kern einer Bibliothekswissenschaft zu setzen.

Schlüsselwörter: New Librarianschip; DIKW; Informationszeitalter; Wissen; Community; Conversation Theory; Beteiligung; Lernen

Henrik Jochumsen: How to Qualify the Debate on the Public Library by the Use of Research-Developed Tools

[Wie kann die Debatte über die öffentliche Bibliothek durch den Gebrauch von forschungsbezogenen Werkzeugen qualifiziert werden?] In: BIBLIOTHEK 42 (2018) Nr. 2, S. 344-350

Zusammenfassung: Der vorliegende Aufsatz versteht sich als Bereicherung der Debatte über die öffentlichen Bibliotheken durch den Gebrauch forschungsbasierter Modelle und Konzepte. Es werden dazu drei solcher Modelle/Konzepte diskutiert (das Vier-Raum-Modell, das Drei-Funktionen-Modell und das Konzept des „New Librarianship“) und die Möglichkeiten ausgelotet, wie sie dazu helfen können, den Krisendiskurs zu überwinden, der die öffentliche Debatte in hohem Maße prägt.

Schlüsselwörter: Öffentliche Bibliotheken; Bibliotheksentwicklung; Bibliotheksdebatte

Jean-Michel Salaün: Die drei Dimensionen des Dokuments und ihre Auswirkungen auf die Bibliotheks- und Informationswissenschaft

In: BIBLIOTHEK 42 (2018) Nr. 2, S. 351-356

Zusammenfassung: Das Dokument wird in seinen drei Dimensionen analysiert: die Form, der Inhalt und die Funktion der Vermittlung. Das Web wird als die Erscheinungsform einer neuen dokumentarischen Ordnung verstanden, die geeigneter ist, den Anforderungen einer tief- greifend gewandelten Welt $\mathrm{zu}$ entsprechen. Apple, Google, Facebook, jede der drei Firmen setzen jeweils auf eine der drei Dokumentdimensionen. Die Informationsarchitektur lässt neue professionelle Kompetenzen entstehen, die zur unumgänglichen Erneuerung der Informationswissenschaften beitragen könnten.

Schlüsselwörter: Dokument; Pédauque; Gütertypologie; Nicht-Rivalität von Information; Informationsarchitektur; Lesen; Text; Bibliothek als Medium; Umbruch der dokumentarischen Ordnung; Spätmoderne

Ragnar Andreas Audunson: Do We Need a New Approach to Library and Information Science?

[Brauchen wir einen neuen Ansatz für die Bibliotheks- und Informationswissenschaften?]

In: BIBLIOTHEK 42 (2018) Nr. 2, S. 357-362

Zusammenfassung: Der vorliegende Beitrag analysiert den durch die Digitalisierung bedingten Druck auf das Bibliothekswesen und die Bibliotheks- und Informationswissenschaft sowie auf die zunehmende Bedeutung der Bibliotheken als Begegnungsorte und -arenen für die Öffentlichkeit. Beide Entwicklungstendenzen stellen die Notwendigkeit von Bibliothekaren als Vermittler zwischen Nutzern und Informationsquellen in Frage. Das Navigieren und Suchen nach Informationen in einer digitalen Welt, wenn die Welt selbst eine Bibliothek geworden ist, ist alles andere als trivial und die traditionellen Kompetenzen der Bibliothekare in Bezug auf das Suchen und Finden von Informationen sind so relevant wie eh und je. LIS-Ausbildungseinrichtungen sollten ihren Studenten auch die theoretische Werkzeuge zur Verfügung stellen, die ihnen helfen, über die Rolle und das Potenzial von Bibliotheken in Bezug auf die Herausforderungen einer nachhaltigen öffentlichen Sphäre im digitalen und multikulturellen Zeitalter nachzudenken. LIS-Ausbildungseinrichtungen sollten ihren Studenten auch die historische Kontinuität und das Erbe von Bibliotheken als Institutionen der öffentlichen Sphäre vermitteln.

Schlüsselwörter: Bibliothek als Ort der Öffentlichkeit; Arena; Demokratie; soziale Prozesse; Berufsethos; Bildung

Rob Bruijnzeels und Joyce Sternheim: Bibliotheken mit Vorstellungskraft - Bausteine für einen Lehrplan für zukünftige Bibliotheksarbeit

In: BIBLIOTHEK 42 (2018) Nr. 2, S. 363-369

Zusammenfassung: Um die Wissensschaffung und Interaktion in ihren Gemeinschaften zu verbessern, müssen Bibliotheken die kollektiven Kenntnisse der Menschen nutzen und deren Aktivitäten und Wissen in ihre Sammlung einbeziehen. Um dies zu erreichen, hat das niederländische Ministerium für Vorstellungskraft einen neuen 
Arbeitsprozess entwickelt, der die Nutzung des Bibliotheksraums berücksichtigt und zu einem neuen Lehrplan für Bibliothekare und einer neuen Typologie für öffentliche Bibliotheksgebäude führen könnte.

Schlüsselwörter: Architektur; Bibliotheksbestand; konzeptuelles Zeitalter; Partizipation; Kreativität; Curriculum

Nikolaus Wegmann: Im Labyrinth. Über die (Un-)Möglichkeit der Bibliothek als Qualitätsmedium In: BIBLIOTHEK 42 (2018) Nr. 2, S. 370-378

Zusammenfassung: Ausgehend von der Fallstudie der Bibliotheksbenutzung durch Johann Wolfgang von Goethe wird die Operation des Suchens und Findens speziell in der Bibliothek als risikoreiches Eintreten in ein Labyrinth beschrieben. Den aktuellen Versuchen gerade auch nutzerorientierter Formalisierung des Suchprozesses wird entgegen gehalten, dass diese nicht der eigentlichen „Qualität“ der Bibliothek entsprechen. Es wird eine Bibliothekskritik gefordert, die das Operative des Findens jenseits von Recommender-Systemen und einfacher Serendipity in den Blick nimmt.

Schlüsselwörter: Bibliothekskritik; Labyrinth; Risiko; Suchen und Finden; Serendipity; Recommender-System; Informationsbewertung; Selektion; Johann Wolfgang von Goethe

Wolfgang Ernst: Die Unwahrscheinlichkeit von Wissenstradition und die Beharrlichkeit der Bibliothek

In: BIBLIOTHEK 42 (2018) Nr. 2, S. 379-386

Zusammenfassung: Mit dem Wandel der Leitmedien von der Buchform zur Zeitform ändert sich der Auftrag der Bibliothek oder lässt diesen zumindest deutlicher erscheinen: Sie hat ihre Rolle im kybernetischen Denken der Wissenszirkulation zu aktualisieren als Zeitkanal zwischen materieller Entropie und ordnungsbewahrender Negentropie. Zwar ist der Hypertext eine aktuelle Alternative zum raumbezogenen Gedächtnis und eröffnet neue Optionen der Wissensnavigation, doch angesichts der Zerstreuung in Netzarchitekturen bedarf es der Bibliothek, um dem Verlust der Nachhaltigkeit von Online-Wissen katechontisch (verzögernd) entgegenzuwirken.

Schlüsselwörter: Bibliothek als Zeitkanal; Bibliothek als Medium; Buchform vs. Zeitform; Medienwissenschaft 


\section{Contents Page}

This Contents page may be reproduced without charge.

Stefan Münnich: Ontologien als semantische Zündstufe für die digitale Musikwissenschaft? Eine Bestandsaufnahme [Ontologies as a Semantic Booster for Digital Musicology? An Overview]

In: BIBLIOTHEK 42 (2018) Nr. 2, S. S. 184-193

Abstract: Ontologies play a crucial role for the formalised representation of knowledge and information as well as for the infrastructure of the semantic web. Despite early initiatives that were driven by libraries and memory institutions, German musicology as a whole has turned very slowly to the subject. In an overview the author addresses basic concepts, challenges, and approaches for ontology design and identifies models and use cases with promising applications for a ,semantic' digital musicology.

Keywords: Semantic web; ontologies; knowledge representation; digital musicology

Pasquale Lisena, Manel Achichi, Pierre Choffé, Cécile Cecconi, Konstantin Todorov, Bernard Jacquemin and Raphaël Troncy: Improving (Re-) Usability of Musical Datasets: An Overview of the DOREMUS Project In: BIBLIOTHEK 42 (2018) Nr. 2, S. 194-205

Abstract: DOREMUS works on a better description of music by building new tools to link and explore the data of three French institutions. This paper gives an overview of the data model based on FRBRoo explaining the conversion and linking processes using linked data technologies and presenting the prototypes created to consume the data according to the web users' needs.

Keywords: FRBRoo; music works; semantic web; data conversion; data interlinking; musical practices; recommendation tools

Terhi Nurmikko-Fuller, Daniel Bangert, Alan Dix, David Weigl and Kevin Page: Building Prototypes Aggregating Musicological Datasets on the Semantic Web In: BIBLIOTHEK 42 (2018) Nr. 2, S. 206-221

Abstract: Semantic Web technologies such as RDF, OWL, and SPARQL can be successfully used to bridge complementary musicological information. In this paper, we describe, compare, and evaluate the datasets and workflows used to create two such aggregator projects: In Collaboration with In Concert, and JazzCats, both of which bring together a cluster of smaller projects containing concert and performance metadata.

Keywords: Musicology; ontology; workflow
Katrin Bicher and Barbara Wiermann: Normdaten zu „Werken der Musik“ und ihr Potenzial für die digitale Musikwissenschaft

[Authority Files for Musical Works and their Potential for

Digital Musicology]

In: BIBLIOTHEK 42 (2018) Nr. 2, S. 222-235

Abstract: The paper discusses conceptual matters and implementation practices for authority information for musical works in the German authority file (GND). Options of re-use of the authority data in libraries as well as in musicological contexts are introduced. Challenges of theoretical concepts as well as practical realization are shown and potentials of information included in authority files are demonstrated.

Keywords: Authority files; musical works; library catalog; digital musicology

Andreas Münzmay: Lesen und Schreiben im digitalen Dickicht. Musikwissenschaft, Digital Humanities und die hybride Musikbibliothek

[Reading and Writing in the Digital Thicket: Musicology, Digital Humanities, and the Hybrid Music Library] In: BIBLIOTHEK 42 (2018) Nr. 2, S. 236-246

Abstract: Digitization produces ,hybrid“ objects that are readable as digital data files but at the same time still ,contain' the original cultural-historical object. In this perspective, ,digital collections', ,digital libraries', etc. are in fact hybrid collections, or libraries. For musical artefacts, the range of historical media is especially complex, which again concerns the digital world. Digital Humanities publications also contribute to the complex and confusing situation as they themselves are not only ,information', but as a rule, complex and hybrid textual systems that often contain complete digitized re-publications of cultural objects, providing them with digital, inscriptions', and interlinking them. So the hybridity of ,digital libraries' increases as soon as Digital Humanities publications are integrated. Therefore, metadata should mirror precisely the hybrid nature of the digitized/digital objects catalogued.

Keywords: ,Hybrid“ objects; digital library; digital humanities; metadata, catalogue

Christiane Hausmann: Bach digital: Ein „work in progress“ der digitalen Musikwissenschaft

[Bach digital: Work in Progress for Digital Musicology]

In: BIBLIOTHEK 42 (2018) Nr. 2, S. 247-254

Abstract: The article outlines the content-technical development of the composer-database Bach digital and ex- 
plains the project goals. Consequently, on the one hand, the challenges and problems of digital long-term projects are identified. On the other hand, it is shown how the organization and presentation of research results are transformed by the development of a complex digital research instrument and which changes result from it for the musicological work and the research communication.

Keywords: Digitisation; Composers-Database; J.S. Bach; Bach-family

Patrizia Rebulla, Pierluigi Ledda and Helen Müller: The letters of Casa Ricordi

In: BIBLIOTHEK 42 (2018) Nr. 2, S. 255-262

Abstract: The Archivio Storico Ricordi holds the historical records of one of the most important music publisher of all times. For almost two hundred years, beyond their main business as music publishers, the Ricordis were also impresarios, agents, and cultural organisers, and played a central and unique mediating role within Italian musical life. This role is very well documented by some 30,000 autograph letters addressed to Casa Ricordi by composers, writers, librettists, singers, and conductors, and an impressive and neatly ordered collection of around 600,000 sent letters. The whole collection will be published online bit by bit. The goal of the project is to connect the letters not only with the relevant records of the Ricordi archive (ledgers, contracts, stage designs, scores, pictures...), but also with other music archives over the web.

Keywords: Publishing house archive; letter indexing; manuscript OCR; crowdsourcing

Frédéric Lemmers: Digitizing Sound Archives at Royal Library of Belgium

In: BIBLIOTHEK 42 (2018) Nr. 2, S. 263-271

Abstract: Music in general and recorded music in particular are rarely a priority for libraries' digitization policies, although wax cylinders and 78rpm discs might be digitized for preservation and accessibility reasons. The respect of the original recording technique during the digitization process will ensure the scientific and artistic credibility of the digitized sources. The Royal Library of Belgium started in 2016 the digitization of its whole collection of 78rpm. Realized by subcontracting, this project of about 4,000 hours will constitute a large corpus of sources for the digital musicology upcoming needs.

Keywords: Sound recordings; digitization; user expectations; audio-turn

Karolin Schmahl: Open Cultural Heritage - zum Hören!

[Open Cultural Heritage - For Hearing!]

In: BIBLIOTHEK 42 (2018) Nr. 2, S. 272-283
Abstract: Digital or digitized sound recordings are increasingly demanded, and important sources for science. As documents of cultural heritage, they are also of great interest to the general public. However, providing freely accessible audio documents online as Open Cultural Heritage is often difficult for libraries and archives in practice. The article sketches the specific challenges of digitizing and publishing sound documents and outlines - also on the basis of practical examples - different ways in which collections can meet the requirements of open science.

Keywords: Audio materials; Open Science; digitization

Christian Liebl: Zur Edition historischer Tonaufnahmen -

ein Praxisbericht

[On the Edition of Historical Sound Recordings - Reflections and Workflows]

In: BIBLIOTHEK 42 (2018) Nr. 2, S. 284-291

Abstract: Following the code of practice established by the Phonogrammarchiv of the Austrian Academy of Sciences, this contribution - alongside some general reflections presents two workflows on the content-related and technical aspects of an annotated edition of historical sound recordings. The topics include source-critical preparation and contextualisation as well as re-recording, digitisation, and signal processing.

Keywords: Historical sound recordings; edition; re-recording; signal processing

Joachim Veit and Kristina Richts: Stand und Perspektiven der Nutzung von MEl in der Musikwissenschaft und in Bibliotheken

[Current Status and Perspectives of MEI Usage in Musicology and in Libraries] In: BIBLIOTHEK 42 (2018) Nr. 2, S. 292-301

Abstract: Starting from the description of the development of MEI (which has to be seen in parallel with TEI) the paper deals with the perspectives of the usage of this format, which was designed for scholarly purposes and, in the library context, has high potentials especially in the header-section. The role of facsimiles in editions illustrates how this format might contribute to a new way of collaboration between the scholarly and the library world.

Keywords: Data Standards; Music Encoding Initiative (MEI); metadata; TEI

Daniel Röwenstrunk: Langzeitverfügbarkeit von wissenschaftlicher Software im Bereich historisch-kritischer Musikedition [Long-term Availability of Research Software in the Field of Historic-critical Music Editions] In: BIBLIOTHEK 42 (2018) Nr. 2, S. 302-308 
Abstract: Long-term availability of research findings is a challenge for research, software development, and memory institutions altogether. This often includes the necessity to keep research software running over a long time. There are various methods and actions like standardization, emulation, or the development of research software by an open source community which can be taken to achieve this goal.

Keywords: Research software; long-term availability; digital music editions

Klaus Keil and Laurent Pugin: Das Internationale Quellenlexikon der Musik, RISM. Ein Gemeinschaftsprojekt zum Nutzen und als Aufgabe für Forschung und Bibliotheken [The International Inventory of Musical Sources (RISM). A Joint Project of Research Institutions and Libraries] In: BIBLIOTHEK 42 (2018) Nr. 2, S. 309-318

Abstract: The International Inventory of musical Sources (RISM) is an international joint project with the aim of comprehensively documenting the sources of music worldwide. It offers an online catalogue that is available free of charge to librarians, musicians, scientists and all interested people. Increasingly, however, the exchange of data comes to the fore, be it from local online library catalogues to RISM or vice versa. For the science, the reuse of the data, which are available as open data as well as linked open data, may be of interest in special projects.

Keywords: Music sources; online cataloguing; authority files; MEI; visualization; digitization; IIIF

Jürgen Diet: Optical Music Recognition in der Bayerischen Staatsbibliothek

[Optical Music Recognition in the Bavarian State Library] In: BIBLIOTHEK 42 (2018) Nr. 2, S. 319-323

Abstract: During summer 2016, the Bavarian State Library has started a project on optical music recognition (OMR). This paper describes the functionality and quality of OMRprograms at first and then depicts the OMR-experiences of the Bavarian State Library. Finally, the use case scenarios are outlined that the Bavarian State Library will implement on top of the OMR data.

Keywords: Optical music recognition; melody search

Manuel Burghardt: Digital Humanities in der Musikwissenschaft - Computergestützte Erschließungsstrategien und Analyseansätze für handschriftliche Liedblätter [Digital Humanities in Musicology - Toward Computer-based Transcription and Analysis of Handwritten Music Scores] In: BIBLIOTHEK 42 (2018) Nr. 2, S. 324-332

Abstract: This article presents an ongoing project for the computer-based transcription and analysis of handwritten music scores from a large collection of German folk tunes.
Based on this project, I will discuss the challenges and opportunities that arise when using Digital Humanities methods in musicology.

Keywords: Digital Humanities; Crowdsourcing; Optical Music Recognition; Music Information Retrieval; Melodic Similarity

Hans-Christoph Hobohm: Warum brauchen wir eine (neue) Bibliothekswissenschaft? Editorial

[Why Do We Need Library Science? An Editorial] In: BIBLIOTHEK 42 (2018) Nr. 2, S. 333-337

Abstract: The turn during the digital transformation is questioning a lot of institutions; but not the library which seems to be an institution better off than expected for a long time. This may be seen in the light of recent successful library project either in the public sphere as well as in the field of research and academic libraries. The thematic focus collects statements from researchers coming from diverse cultures or disciplines arguing for a renewal of Library Science in the light of the digital.

Keywords: Library science; renewal; dataism; knowledge; social epistemology

\section{R. David Lankes: Why Do We Need a New Library Science} In: BIBLIOTHEK 42 (2018) Nr. 2, S. 338-343

Abstract: A Library is not just an information distributing machine and reading not its steam as the paradigm of the industrial age has seen it. Even the conception of the Library as Information Agency established in the 20th century does not meet any more the needs of our communities. In the age of data'ism the Library is not about Information as a thing and neutral IT infrastructures. It needs a more critical world view. Instead of data and information a new library science should focus on knowledge and knowing. The communities library serve are the true collections; librarians the weavers of community narratives and understandings.

Keywords: New librarianship; DIKW; information age; knowledge; community; conversation theory; participation; learning

Henrik Jochumsen: How to Qualify the Debate on the Public Library by the Use of Research-Developed Tools In: BIBLIOTHEK 42 (2018) Nr. 2, S. 344-350

Abstract: The article discusses how it is possible to qualify the debate on public libraries by the use of research based models and concepts and hereby maybe even change the crisis discourse that according to the author characterizes the public debate on current library development. Keyelements are the four-space model, the three-function model and the concept of "New Librarianship". 
Keywords: Public Libraries; library development; library debate

Jean-Michel Salaün: Die drei Dimensionen des Dokuments und ihre Auswirkungen auf die Bibliotheks- und Informationswissenschaft

[The three Dimensions of a Document and its Reflexion on Library and Information Science] In: BIBLIOTHEK 42 (2018) Nr. 2, S. 351-356

Abstract: The document is analyzed in its three dimensions: the form, the content, and the mediation. The Web is understood as the manifestation of a new document sphere, which is more able to satisfy the challenges of a world in profound change. Apple, Google, and Facebook exploit either of the three document dimensions. The discipline of IA „Information Architecture“ helps to develop new professional competencies which could contribute to an inevitable renewal of information sciences.

Keywords: Document; Pédauque; typology of goods; nonrivaltry of information; information architecture; reading; text; revolution of the documentary order; library as a medium; late modernity

Ragnar Andreas Audunson: Do We Need a New Approach to Library and Information Science?

In: BIBLIOTHEK 42 (2018) Nr. 2, S. 357-362

Abstract: This article analyses the pressure against librarianship and library and information science stemming from digitization and the increased importance attached to libraries' role as meeting places and arenas for the public sphere. Both these developmental tendencies make many question the need of librarians as intermediaries between users and the sources of information. The navigating and searching for information in a digital world when the world itself has become a library, is far from trivial and the traditional competencies of librarians relating to searching for and finding information is as relevant as ever. LIS schools should also provide their students with theoretical tools helping them reflect upon the role and potential of libraries in relation to the challenges to upholding a sustainable public sphere in a digital and multicultural age. LIS schools should also convey to their students the historical continuity and legacy of libraries as a public sphere institution.

Keywords: Library as meetings place in the public sphere; arena; democracy; social processes; professional civic self-cultivation

Rob Bruijnzeels and Joyce Sternheim: Bibliotheken mit Vorstellungskraft - Bausteine für einen Lehrplan für zukünftige Bibliotheksarbeit
[Libraries for Imagination - Building Blocks for a Curriculum of Future Library Work] In: BIBLIOTHEK 42 (2018) Nr. 2, S. 363-369

Abstract: To enhance knowledge creation and interaction in their communities, libraries need to tap into the collective insight of people and allow their activities and knowledge to become part of the collection. To achieve this, the Dutch Ministry of Imagination has developed a new work process that affects the use of space and could lead to a new curriculum for librarians and a new typology for public library buildings.

Keywords: Architecture; library collection; conceptual age; participation; creativity; curriculum

Nikolaus Wegmann: Im Labyrinth. Über die (Un-)Möglichkeit der Bibliothek als Qualitätsmedium

[Going in the Maze. On the Im-possibility of the Library as a Quality Medium]

In: BIBLIOTHEK 42 (2018) Nr. 2, S. 370-378

Abstract: Taking the case study of library use by Johann Wolfgang von Goethe as a starting point, the operation of searching and finding, especially in the library, is described as a risky entry into a maze. The current attempts especially user-oriented formalizations of the search process is countered that these do not correspond to the actual "quality" of the library. A library criticism is called for, focusing on the process of finding which goes beyond recommender systems and the mere observation of serendipity.

Keywords: Library criticism; maze; risk; search and find; serendipity; recommender system; information appraisal; selection; Johann Wolfgang von Goethe

Wolfgang Ernst: Die Unwahrscheinlichkeit von Wissenstradition und die Beharrlichkeit der Bibliothek

[(Im-)Probabilities of Knowledge Tradition and the Insistence of the Library. de] In: BIBLIOTHEK 42 (2018) Nr. 2, S. 379-386

Abstract: With an increasing transformation of knowledge tradition from material book-based storage to processual time-based data migration, the function of the library is redefined: as time channel, she becomes an agency within the cybernetics of knowledge circuitry. Even if hypertext has liberated knowledge from its restrictions to local memory places, and algorithms provide for new options of data navigation, it is the temporal volatility of net architecture which asks for the library as katechon, as agency of delayed knowledge transfer.

Keywords: Library as a time channel; Library as a medium; from material book-based storage to processual time based data migration 